\title{
MECHANISM OF THE DELAYED PUBERTY ONSET IN OFFSPRING OF RATS THAT CONSUMED AQUEOUS EXTRACT OF HIBISCUS SABDARIFFA DURING PREGNANCY
}

\author{
E. E. IYARE AND O. A. ADEGOKE \\ Department of Physiology College of Medicine, University of Lagos, Idiaraba, Lagos State, Nigeria. \\ E-mail address: eghosai@yahoo.com (Iyare,E.E.) Tel. +2348052820041
}

\begin{abstract}
Summary: Consumption of extracts of Hibiscus sabdariffa (family: malvaceae) during pregnancy has been shown to cause maternal malnutrition which has been linked to various adverse conditions like increased postnatal weight gain, delayed puberty onset and elevated body weight and body mass index at onset of puberty in the female offspring. The present study was designed to investigate the possible mechanism underlying this. Eighteen in-bred pregnant Sprague-Dawley rats were on day 1 of pregnancy, randomly divided into three groups of six animals each. Group A (control) was given tap water to drink. Group B was given 0.6g extract/100ml while Group $\mathrm{C}$ was given $1.8 \mathrm{~g}$ extract/100ml as their drinking solution. All groups received normal rat chow and their drinking solution ad libitum. Fluid and food intake and dam weights were measured daily throughout pregnancy. On gestational day 18, blood sample was withdrawn from each rat for estimation of plasma $\mathrm{Na}$ ion and corticosterone levels. On the day of delivery, the solutions of the extracts of Hibiscus sabdariffa were withdrawn and replaced with tap water. After 21 days, the pups were weaned to tap water and food ad libitum. Pups weight and age and body mass index at onset of puberty were measured. The results of the present study showed that the increased postnatal weight gain, delayed puberty onset and elevated body mass index at onset of puberty in the offspring of rats that consumed HS during pregnancy was associated with elevated maternal plasma $\mathrm{Na}$ ion and corticosterone levels during pregnancy.
\end{abstract}

Keywords: Hibiscus sabdariffa; delayed puberty onset; rat offspring

\section{Introduction}

Extracts of Hibiscus sabdariffa (HS) (family: malvaceae) are widely believed in folk medicine to be effective in the treatment of a variety of ailments (Perry, 1980; Watt et al, 1962; Oliver, 1960). The effectiveness of HS in the treatment of these ailments have been attributable to the various constituents of HS like flavonoids, anthocyanins, organic acids, $\mathrm{Na}^{+}$, vitamins $\mathrm{A}$ and $\mathrm{C}$ and $\mathrm{Fe}$ (Fuleki and Francis, 1968; Clydesdale, 1979; Duke and Francis, 1973; Morton, 1987; Daffalah and alMustafa, 1996; Appel, 2003; Adigun et al, 2006). Zobo drink, a sweetened beverage made from the aqueous extract of HS, is commonly produced, sold and consumed by Nigerians of all ages (irrespective of gender and physiologic state), not necessarily for its medicinal properties, but as a substitute for carbonated drinks or fruit juices because of the immense cost difference and the ready availability of HS.

We have earlier shown that rats given aqueous extract of HS to drink throughout pregnancy drank less fluid and consumed less food (Iyare and Adegoke, 2008a,b,c). The effect of reduced maternal food consumption during pregnancy on the developmental outcome of the offspring is well known. For example, maternal malnutrition during pregnancy has been linked to various adverse conditions like hypertensive, metabolic and reproductive disorders in the offspring in adult life
(Armitage et al, 2005a,b; Gluckman and Hanson, 2004; Barker et al, 1993).

We have also shown that the offspring of rats given aqueous extract of HS to drink throughout pregnancy have increased postnatal weight gain, delayed onset of puberty and elevated body weight and body mass index at onset of puberty (Iyare and Adegoke, 2008a,b) through mechanism that was not clear. The present study was designed to investigate the possible mechanism by which maternal consumption of aqueous extract of HS during pregnancy mediated the observed effects in the offspring.

\section{Materials and Methods \\ Experimental_animal}

Eighteen in-bred virgin female SpragueDawley rats aged between 10-12 weeks and weighing $125 \pm 5.5 \mathrm{~g} \quad($ mean \pm SEM) with two consecutive regular 4-day estrus cycle were used for this study. These rats were housed individually in cages under standard environmental conditions. The estrous cycles were monitored and male rats of proven fertility were introduced into the cages of the female rats that were expected to get into the estrous phase within 12 hours to allow for mating. Day 1 of pregnancy was taken as the day sperm were seen in the vaginal smear of the rats. On day 1 of pregnancy, animals were divided randomly into three groups of six animals each. Group A (control) 
was given tap water to drink. Group B was given $0.6 \mathrm{~g}$-extract $/ 100 \mathrm{ml}$ while Group $\mathrm{C}$ was given $1.8 \mathrm{~g}$ extract/100ml as their drinking solution. All groups received normal rat chow and their drinking solution ad libitum. Fluid and food intake and dam weights were measured daily throughout pregnancy and at delivery.

On the day of delivery, the HS solutions were withdrawn and replaced with tap water. Each dam in each group was allowed 9 pups to nurse throughout the lactational period so as to eliminate the effect of undernutrition or overnutrition of some of the pups. After 21 days, the pups were weaned to tap water and thereafter, the female pups were kept in groups of three per cage. Pups' weights were recorded at birth, weaning and weekly thereafter till onset of puberty. Pubertal development starts soon after weaning, so from postnatal day 30 onwards, the young female rats were inspected daily for vaginal opening since onset of puberty is defined as the age (in days) at which vaginal opening occurs (Engelbregt et al., 2000). At onset of puberty, age, body weight, body length and body mass index were recorded.

\section{Flame photometry and radioimmunoassay:}

On gestational day 18 , blood sample was withdrawn from the orbital sinus of each rat in each group. The blood sample was then put in a heparinised tube and centrifuged. The sodium ion content of the plasma was assessed by flame photometry and the corticosterone level was assayed by radioimmunoassay.

\section{Extraction procedure:}

Mature dry dark-red calyces of HS were purchased from a local market in Lagos, Nigeria and authenticated by $\mathrm{Mr}$ T.I. Adeleke of the department of Pharmacognosy, University of Lagos, Nigeria where a voucher specimen number PCG H455 was deposited. The extraction procedure used in our laboratory was as described previously (Iyare and Adegoke, 2008a,b). Briefly, $30 \mathrm{~g}$ of the dry petals of HS was brewed in $400 \mathrm{ml}$ of boiled tap water for $45 \mathrm{~min}$. The resulting decoction was filtered and evaporated to dryness giving a dark red powder (yield $48.87 \%$ ).

$0.6 \mathrm{~g}$ and $1.8 \mathrm{~g}$ of the dark red powder were weighed and dissolved in $100 \mathrm{ml}$ of tap water and then given to groups $\mathrm{B}$ and $\mathrm{C}$ respectively as their drinking solution.

\section{Statistical analysis:}

The Student's t-test for paired data was used to analyze data from the same group of rats. For data comparison between the three groups, the one way analysis of variance (ANOVA) was used followed by a post-hoc Student's Newman-Keuls test. $\mathrm{P}<0.05$ was taken as statistically significant.

\section{Results}

Maternal Fluid and Food intake

There was a significant decrease in maternal fluid and food consumption in each trimester in dams that consumed HS (HS dams) during pregnancy (Tables 1 and 2). There was no significant difference in the fluid and food consumption between the two groups of HS dams except in the second trimester when the fluid and food consumption were significantly lower in the $1.8 \mathrm{~g} / 100 \mathrm{ml}$ group.

Table 1: Effect of consumption of Hibiscus sabdariffa during pregnancy on mean fluid consumption Mean fluid intake (ml/day)

\begin{tabular}{cccc}
\hline $\begin{array}{c}\text { Dose of HS } \\
\text { consumed }\end{array}$ & $1^{\text {st }}$ trimester & $\begin{array}{c}2^{\text {nd }} \\
\text { trimester }\end{array}$ & $\begin{array}{c}3^{\text {rd }} \\
\text { trimester }\end{array}$ \\
0 (Control) & $31.0 \pm 0.97$ & $36.17 \pm$ & $29.17 \pm$ \\
& & 1.22 & 1.45 \\
$0.6 \mathrm{~g} / 100 \mathrm{ml}$ & $18.33 \pm 0.95^{*}$ & $22.0 \pm$ & $23.33 \pm$ \\
& & $1.03^{*}$ & $0.99^{*}$ \\
$1.8 \mathrm{~g} / 100 \mathrm{ml}$ & $17.33 \pm 0.84^{*}$ & $18.5 \pm$ & $24.17 \pm$ \\
& & $0.65^{\mathrm{P}}$ & $0.54^{*}$ \\
& & & \\
\end{tabular}

HS = Hibiscus sabdariffa, Control = tap water (no HS). $N=6$ each. ${ }^{*}=\mathrm{P}<0.05$ vs Control, ${ }^{\mathrm{P}}=\mathrm{P}<0.05$ vs Control and $0.6 \mathrm{~g} / 100 \mathrm{ml}$. Values are expressed as Mean \pm SEM.

Table 2: Effect of consumption of Hibiscus sabdariffa during pregnancy on mean food consumption

\begin{tabular}{|c|c|c|c|}
\hline \multicolumn{4}{|c|}{ Mean food intake (g/day) } \\
\hline $\begin{array}{c}\text { Dose of HS } \\
\text { consumed }\end{array}$ & $\begin{array}{c}1^{\mathrm{st}} \\
\text { trimester }\end{array}$ & $\begin{array}{c}2^{\text {nd }} \\
\text { trimester }\end{array}$ & $\begin{array}{c}3^{\text {rd }} \\
\text { trimester }\end{array}$ \\
\hline 0 (Control) & $\begin{array}{c}21.0 \pm \\
1.46\end{array}$ & $\begin{array}{c}27.33 \pm \\
0.95\end{array}$ & $\begin{array}{c}24.17 \pm \\
0.83\end{array}$ \\
\hline $0.6 \mathrm{~g} / 100 \mathrm{ml}$ & $\begin{array}{l}17.0 \pm \\
0.73^{*}\end{array}$ & $\begin{array}{c}22.33 \pm \\
1.20^{*}\end{array}$ & $\begin{array}{l}21.0 \pm \\
0.73^{*}\end{array}$ \\
\hline $1.8 \mathrm{~g} / 100 \mathrm{ml}$ & $\begin{array}{l}17.5 \pm \\
1.28 *\end{array}$ & $\begin{array}{c}17.83 \pm \\
0.79^{\mathrm{P}}\end{array}$ & $\begin{array}{l}18.5 \pm \\
0.89^{*}\end{array}$ \\
\hline
\end{tabular}

$H S=$ Hibiscus sabdariffa, Control = tap water $($ no $H S)$. $N=6$ each. ${ }^{*}=P<0.05$ vs Control, ${ }^{P}=P<0.05$ vs Control and $0.6 \mathrm{~g} / 100 \mathrm{ml}$. Values are expressed as Mean \pm SEM.

\section{Weight gain during pregnancy}

There was a significantly reduced weight gain in the $1^{\text {st }}$ trimester of pregnancy in the HS dams compared with the control dams (Table 3). In the $2^{\text {nd }}$ trimester, only the HS dams in the $1.8 \mathrm{~g} / 100 \mathrm{ml}$ group had a significantly reduced weight gain compared with the control dams. There was no 
difference in weight gain between the $1^{\text {st }}$ and $2^{\text {nd }}$ trimesters among the three groups except in the $0.6 \mathrm{~g} / 100 \mathrm{ml}$ group where the weight gain in the $2^{\text {nd }}$ trimester was significantly higher than that of the $1^{\text {st }}$ trimester. There was no difference in weight gain among the three groups in the $3^{\text {rd }}$ trimester. The weight gain in the $3^{\text {rd }}$ trimester in the three groups was significantly higher than the weight gain in the $1^{\text {st }}$ and $2^{\text {nd }}$ trimester.

Plasma $\mathrm{Na}^{+}$and corticosterone concentration

There was a significant increase in plasma $\mathrm{Na}^{+}$and corticosterone concentration in the HS groups compared with the control group (Table 4). The effect of HS on corticosterone concentration appeared to be dose-dependent since the level of corticosterone in the dams in the $1.8 \mathrm{~g} / 100 \mathrm{ml}$ group was higher than that in the $0.6 \mathrm{~g} / 100 \mathrm{ml}$ group.

Offspring birth weight and age, body weight, body length and BMI at onset of puberty

The birth weight of the offspring in the HS groups was significantly higher than that in the control group (Table 5). The offspring of the HS dams also had significantly delayed onset of puberty coupled with elevated body weight, body length and body mass index.

Table 3: Effect of maternal consumption of Hibiscus sabdariffa on weight gain in each trimester of pregnancy.

\begin{tabular}{cccc}
\hline \multicolumn{4}{c}{ Absolute weight gain $(\mathrm{g})$} \\
$\begin{array}{c}\text { Dose of } \\
\text { HS } \\
\text { consumed }\end{array}$ & $\begin{array}{c}1^{\text {st }} \\
\text { trimester }\end{array}$ & $\begin{array}{c}2^{\text {nd }} \\
\text { trimester }\end{array}$ & $3^{\text {rd }}$ \\
trimester \\
$0($ Control $)$ & $26.3 \pm 1.6$ & $30.5 \pm 1.8$ & $45.6 \pm 1.9^{\#}$ \\
$0.6 \mathrm{~g} / 100 \mathrm{ml}$ & $21.2 \pm 0.7^{*}$ & $26.2 \pm 0.7^{\$}$ & $41.8 \pm 0.9^{\#}$ \\
$1.8 \mathrm{~g} / 100 \mathrm{ml}$ & $19.3 \pm 2.1^{*}$ & $22.5 \pm 2.0^{*}$ & $38.1 \pm 6.1^{\#}$ \\
\hline
\end{tabular}

HS = Hibiscus sabdariffa, Control = tap water (no HS). $N=6$ each. ${ }^{*}=\mathrm{P}<0.05$ vs Control. ${ }^{\$}=\mathrm{P}<0.05$ vs $1^{\text {st }}$ trimester, ${ }^{\#}=\mathrm{P}<0.05$ vs $1^{\text {st }}$ and $2^{\text {nd }}$ trimester. Values are expressed as Mean \pm SEM.

Table 4: Effect of consumption of aqueous extract of Hibiscus sabdariffa during pregnancy on plasma $\mathrm{Na}^{+}$ and corticosterone concentration.

$\begin{array}{lcc}\begin{array}{l}\text { Doses of } \\ \text { consumed }\end{array} & \mathrm{HS} \mathrm{Na}^{+}(\mathrm{mmol} / \mathrm{L}) & \begin{array}{c}\text { Corticosterone } \\ (\mathrm{ng} / \mathrm{ml})\end{array} \\ & & \\ 0(\mathrm{Control}) & 135.0 \pm 0.73 & 12.00 .26 \\ 0.6 \mathrm{~g} / 100 \mathrm{ml} & 143.0 \pm 0.93^{*} & 13.670 .61^{*} \\ 1.8 \mathrm{~g} / 100 \mathrm{ml} & 144.0 \pm 1.15^{*} & 18.00 .58^{\mathrm{P}}\end{array}$

HS = Hibiscus sabdariffa, Control = tap water (no HS). $N=6$ each. ${ }^{*}=\mathrm{P}<0.05$ vs Control. ${ }^{\mathrm{P}}=\mathrm{P}<0.05$ vs Control and $0.6 \mathrm{~g} / 100 \mathrm{ml}$. Values are expressed as Mean \pm SEM.

\section{Discussion}

The results of the present study showed that rats that consumed HS during pregnancy (HS dams) had decreased fluid and food consumption, decreased pregnancy weight gain and increased plasma $\mathrm{Na}^{+}$. This is in agreement with several other reports (Mojiminiyi et al, 2000; Orisakwe et al, 2004; Ojokoh, 2006; Iyare and Adegoke, 2008a,b,c).

Since maternal malnutrition during pregnancy has been shown to result in low birth weight offspring (Barker, 2000; Seckl, 1998; Philips et al, 1998; Lesage et al, 2001; Fowden and Forhead, 2004), the reduced maternal food intake induced by HS consumption in this study, surprisingly, did not result in low birth weight offspring. This may be due to a variety of reasons. Firstly, the developing foetuses of the HS dams may have recruited adaptive mechanisms to protect their growth (Gluckman and Hansen, 2004a,b) and/or the malnutrition in the HS dams that commenced early in pregnancy, may have caused placental development that favoured increased nutrient delivery to the developing foetuses (Woodall et al, 1996; Osgerby et al, 2002; Fowden et al, 2006). Thirdly, the constituents of HS may have directly influenced the growth of the foetuses. For example, vitamin C (Jain et al, 2008; Wu et al, 2008; Yajnik, 2006), vitamin A and Fe (Ceesay et al, 1997; Christian et al, 2003; Yajnik, 2006) and flavonoids (Hilakivi-Klarke et al, 1998) have been shown to have direct growth promoting effect. The elevated glucocorticoid level observed in this study may be due to the osmotic (and the accompanying nutrient stress) stress in the HS dams as a result of the HSinduced increase in plasma $\mathrm{Na}^{+}$concentration (Mojiminiyi et al, 2000; Iyare and Adegoke, 2008b).

For most of pregnancy, the concentration of glucocorticoids in the foetus is low and foetal glucocorticoids are derived from the mother down a concentration gradient through the placenta. This transplacental concentration gradient is maintained by the enzyme $11 \beta$-hydroxysteroid dehydrogenase type-2 (11ßOHSD-2) that converts the active glucocorticoids, cortisol and corticosterone, to their inactive metabolites (Seckl, 2001). This enzyme, therefore, is a key factor in limiting foetal exposure to maternal glucocorticoids. Its placental activity is regulated by nutritional and endocrine factors (Clarke et al, 2002; Seckl, 2001). Thus, it follows that increased foetal glucocorticoid exposure, therefore, occurs due to increased maternal glucocorticoid levels, decreased placental $11 \beta O H S D-2$ activity or increased glucocorticoid output by the foetal adrenal. 
Table 5: Effect of maternal consumption of aqueous extract of Hibiscus sabdariffa during pregnancy on offspring birth weight and age, body weight, body length and BMI at onset of puberty.

Parameters at onset of puberty

$\begin{array}{lccccc}\begin{array}{l}\text { Dose of HS } \\ \text { Consumed }\end{array} & \text { Birth weight } & \text { Age (days) } & \text { Weight }(\mathrm{g}) & \text { Bodylength }(\mathrm{cm}) & \text { BMI }\left(\mathrm{g} / \mathrm{cm}^{2}\right) \\ 0(\text { Control }) & 5.61 \pm 0.14 & 43.11 \pm 1.84 & 58.89 \pm 1.96 & 12.9 \pm 0.15 & 0.35 \pm 0.006 \\ 0.6 \mathrm{~g} / 100 \mathrm{ml} & 6.0 \pm 0.14^{*} & 62.39 \pm 1.84^{\mathrm{P}} & 87.22 \pm 2.52^{*} & 14.02 \pm 0.08^{*} & 0.44 \pm 0.008^{*} \\ 1.8 \mathrm{~g} / 100 \mathrm{ml} & 6.11 \pm 0.12 * & 47.56 \pm 0.73^{*} 94.44 \pm 2.94^{*} & 14.72 \pm 0.104^{\$} & 0.44 \pm 0.011^{*}\end{array}$

$\mathrm{HS}=$ Hibiscus sabdariffa, Control $=$ tap water (no HS). $N=9$ each. Values are expressed as $\mathrm{M} \pm \mathrm{SEM} . \quad *=\mathrm{P}<0.05$ vs Control, ${ }^{\mathrm{P}}=\mathrm{P}<0.05$ vs Control and $1.8 \mathrm{~g} / 100 \mathrm{ml},{ }^{\$}=\mathrm{P}<0.05$ vs Control and $0.6 \mathrm{~g} / 100 \mathrm{ml}$

In the present study, there was increased maternal plasma glucocorticoid level possibly due to the osmotic and nutrient stresses in the HS dams as a result of the HS-induced increase in plasma $\mathrm{Na}^{+}$concentration (Iyare and Adegoke, 2008). In addition, the flavonoids in the HS extract have been shown to inhibit the activity of $11 \beta$ OHSD-2 (Wand et al, 2002; Guo and Reidenberg, 1998; Zhang and Wang, 1997; Lee et al, 1996). This greatly reduces the conversion of the active glucocorticoid to the inactive form and thus increases the level of glucocorticoid reaching the foetus.

Glucocorticoids have been shown to inhibit tissue accretion when their concentrations are elevated beyond the normal physiological levels (Seckl, 2001; Jensen et al, 2002). They have also been shown to have major effects on the differentiation of a wide range of tissues including the lungs, liver, kidneys, muscle, fat and gut (Fowden et al, 1998). They stimulate morphological and functional changes in these tissues and activate many of the biochemical processes which have little or no function in utero but which are essential for survival postnatally (Fowden et al, 1998). Glucocorticoids, therefore, signal adverse intrauterine conditions and adapt fetal development to ensure the maximum chances of survival both in utero and at birth.Since glucocorticoids have been shown to inhibit transplacental leptin flux (Sugden et al, 2001; Smith and Waddel, 2002; 2003), the elevated plasma glucocorticoid level observed in HS dams in this study may have reduced the amount of leptin reaching the foetus from the mother. Leptin plays a significant role in the growth and development of the foetus (Hassink et al, 1997; Ashworth et al, 2000; Yamashita et al, 2001; Smith and Waddell, 2002; 2003) and since in the fed state, circulating levels of leptin and leptin messenger RNA levels are closely correlated with degree of adiposity (Maffei et al, 1995) and leptin levels fall rapidly following food restriction, leptin may therefore act as a metabolic signal to the foetus of the status of maternal energy reserve and by extension, environmental food availability. Low level of leptin in the foetus has been associated with abnormal foetal growth and the induction in the foetus of some of the metabolic adaptations that are designed to enhance postnatal survival under conditions of poor nutrition (Hales and Barker, 1992).

Programming is a process whereby a stimulus or insult acting during critical periods of growth and development may permanently alter tissue structure and function to produce adverse effects in adult life. Increased foetal glucocorticoid and decreased foetal leptin levels have been shown to play significant role in the developmental programming of offspring phenotype in adulthood (Drake et al, 2007; Fowden and Forhead, 2006; Seckl, 2004; McArthur et al, 2006). Specifically, increased foetal glucocorticoid and decreased foetal leptin levels have been shown to delay the onset of puberty in female offspring (Smith and Waddell, 2002; 2003).

From the present study therefore, it can be concluded that the observed increase in postnatal weight gain and the delay in the onset of puberty coupled with elevated BMI in the female offspring of HS dams may have been due to overexposure to glucocorticoids in utero following increased maternal glucocorticoid level induced by HS consumption.

\section{References}

Adigun, M.O., O.D. Ogundipe, J.I. Anetor and A.O. Odetunde (2006). Dose-dependent changes in some haematological parameters during short-term administration of Hibiscus sabdariffa calyx aqueous extract (zobo) in Wistar albino rats. Afr. J. Med. Med. Sci., 35: 73-77.

Appel SD (2003). Red sorrel, Hibiscus sabdariffaThe other "cranberry". Plants and Gardens News. 18: 2.

Armitage, JA, P.D. Taylor and L. Poston (2005a). Experimental models of developmental 
programming: consequences of exposure to an energy rich diet during development. J. Physiol. 15: 565, 3-8.

Armitage, J.A., L. Lakasing, P.D. Taylor, A.A. Balachandran, R.I. Jensen, V. Dekou, N. Ashton, J.R. Nyengaard and L. Poston (2005b). Developmental programming of aortic and renal structure in offspring of rats fed fat-rich diets in pregnancy. J. Physiol. 15: 565: 171-184.

Ashworth CJ, Hoggard N, Thomas L, Mercer JG, Wallace JM, Lea RG (2000). Placental leptin. Rev Reprod 5:18-24.

Barker, DJ (2000). In utero programming of cardiovascular diseases. Theriogenol. 53: 555574.

Barker DJ, Hales CN, Fall CH, Osmond C, Phipps K, Clark PM (1993). Type 2 (non-insulin dependent) diabetes mellitus, hypertension and hyperlipidemia (syndrome $\mathrm{X}$ ): relation to reduced fetal growth. Diabetologia 36: 62-67.

Ceesay SM, Prentice AM, Cole TJ, Foord F, Weaver LT, Poskitt EM, Whitehead RG (1997). Effects on birth weight and perinatal mortality of maternal dietary supplements in rural Gambia: 5 year randomised controlled trial. $\mathrm{Br}$ Med J [Erratum (1997) 315:1141] 315:786790.

Christian P, Khatry SK, Katz J, Pradhan EK, LeClerq SC, Shrestha SR, Adhikari RK, Sommer A, West Jr KP, 2003. Effects of alternative maternal micronutrient supplements on low birth weight in rural Nepal: double blind randomised community trial. Br Med J 326:571.

Clarke KA, Ward JW, Forhead AJ, Giussani DA, Fowden AL (2002). Regulation of $11 \beta$ hydroxysteroid dehydrogenase type 2 activity in ovine placenta by fetal cortisol J. Endocrinol. 172 527-534.

Clydesdale FMC (1979). Roselle (H.S.L.) anthocyanins as colourants for beverages and gelatin deserts. J. Food Protection. 42, 204-267.

Daffalah AA, al-Mustafa Z (1996). Investigation of the anti-inflammatory activity of Acacia nilotica and Hibiscus Sabdariffa. Am J Chin Med 24:263-269.

Drake AJ, Tang JI, Nyirenda MJ (2007). Mechanisms underlying the role of glucocorticoids in the early life programming of adult disease. Clin. Sci. 113: 219-232.

Duke CT and Francis FJ (1973). Anthocyanins of Roselle (H.S.L.). J. Food Sci. 38, 810-812.

Engelbregt MJT, Houdijk MECAM, Popp-Snijders C, Delemarra-van de Waal HA (2000). The effects of intrauterine growth retardation and postnatal undernutrition on onset of puberty in male and female rats. Pediatric Res. 48 (6): 803-807.

Fowden AL, Li J, Forhead AJ (1998). Glucocorticoids and the preparation for life after birth: are there long-term consequences of the life insurance. Proc Nutr Soc 57: 113-122.

Fowden, A.L. and A.J. Forhead (2004). Endocrine mechanisms of intrauterine programming. Reprod., 127: 515-526.

Fowden, AL, J.W. Ward, F.P.B. Wooding, A.J. Forhead and M. Constanci (2006). Programming placental nutrient transport capacity. J. Physiol. 572: 5-15.

Fuleki T and Francis FJ (1968). Determination of total anthocyanin and degradation index. $J$. Food Sci. 33, 78-82.

Gluckman PD, Hanson MA (2004a). Developmental origins of disease paradigm: a mechanistic and evolutionary perspective. Pediatr Res. 56, 311-317.

Gluckman PD, Hanson MA (2004b). The developmental origins of the metabolic syndrome. Trends Endocrinol Metab 15: 183187.

Guo J, Reidenberg MM (1998). Inhibition of 11 beta-hydroxysteroid dehydrogenase by bioflavonoids and their interaction with furosemide and gossypol. J Lab Clin Med Jul ;132 (1):32-38.

Hales CN and Barker DJ (1992). Type 2 (noninsulin-dependent) diabetes mellitus: the thrifty phenotype hypothesis. Diabetologia 35: 595601.

Hassink SG, de Lancey E, Sheslow DV, SmithKirwin SM, O'Connor DM, Considine RV, Opentanova I, Dostal K, Spear ML, Leef K, Ash M, Spitzer AR, Funanage VL (1997). Placental leptin: an important new growth factor in intrauterine and neonatal development? Pediatrics 100:E.1.

Hilakivi-Klarke L, Chow E, Clarke R (1998). Maternal genistein exposure mimics the effects of estrogen on mammary gland development in female mouse offspring. Oncol Rep. 5 (3):609616.

Iyare EE and OA Adegoke (2008a). Postnatal weight gain and onset of puberty in rats exposed to aqueous extract of Hibiscus sabdariffa in utero. Pakistan J. Nutr. 7 (1): 98101.

Iyare EE and OA Adegoke (2008b). Gestational outcome in rats that consumed aqueous extract of Hibiscus sabdariffa during pregnancy. Pakistan J. Nutr. 7. In press.

Iyare EE and OA Adegoke (2008c). Body mass index at onset of puberty in rats exposed to aqueous extract of Hibiscus sabdariffa in utero. Afr. J. Biomed. Res. 11. In press.

Jain SK, Wise R, Yanamandra K, Dhanireddy R, Bocchini JA Jr. (2008). The effect of maternal and cord-blood vitamin $\mathrm{C}$, vitamin $\mathrm{E}$ and lipid peroxide levels on newborn birth weight. Mol Cell Biochem. 309(1-2):217-221. 
Jensen, E. C., Gallaher, B. W., Breier, B. H. and Harding, J. E (2002). The effect of a chronic maternal cortisol infusion on the late-gestation fetal sheep. J. Endocrinol. 174, 27-36.

Lee YS, Lorenzo BJ, Koufis T, Reidenberg MM (1996). Grapefruit juice and its flavonoids inhibit 11 beta-hydroxysteroid dehydrogenase. Clin Pharmacol Ther. 59(1):62-71.

Lesage, J., B. Blondeau, M. Grino, B. Bréant and J.P. Dupouy (2001). Maternal undernutrition during late gestation induces fetal overexposure to glucocorticoids, intrauterine growth retardation and disturbs the hypothalamopituitary adrenal axis in the newborn rat. Endocrinol. 142: 1692-1702.

Maffei MJ, Halaas J, Rayussin E, Pratley RE, Lee GM, Zhang Y, Fei H, Kim S, Lallone R,Ranganathan S (1995). Leptin levels in human and rodent: measurement of plasma leptin and ob mRNA in obese and weightreduced subjects. Nat. Med.1:1155-1161.

McArthur S, Siddique Z.-L., Christian H. C., Capone G., Theogaraj E., John C. D., Smith S. F., Morris J. F., Buckingham J. C., Gillies G. E. (2006). Perinatal Glucocorticoid Treatment Disrupts the Hypothalamo-Lactotroph Axis in Adult Female, But Not Male, Rats. Endocrinol. 147 (4): 1904-1915.

Mojiminiyi, F.B.O., B.J. Adegunloye, Y.A. Egbeniyi and R.U. Okolo (2000). An investigation of the diuretic effect of an aqueous extract of the petals of Hibiscus Sabdariffa. J. Med. Med. Sci., 2 (1): 77-80.

Morton JF (1987). Roselle. In: Fruits of warm climate. Juliaf, Morton and Miami, Florida. 281-286.

Ojokoh AO (2006). Roselle (Hibiscus Sabdariffa) calyx diet and histopathological changes in liver of Albino rats. Pakistan J. Nutr. 5(2) 110-113.

Oliver B (1962). Medicinal plants in Nigeria. Nigerian College of arts, Science and Technology, Ibadan, 16-42.

Orisakwe OE, Hussaini DC, Akunyili DN, Njan AA, Akumka DD, Udemezue OO (2004). Subchronic administration of Nigerian species of Hibiscus Sabdarffa calyx in rats did not produce cardiotoxicity. Euro. Bull. Drug Res. 12: 1-5.

Osgerby, J.C., D.C. Wathes, D. Howard and T.S. Gadd (2002). The effect of maternal undernutrition on ovine fetal growth. $J$. Endocrinol. 173: 131-141.

Perry LM (1980). Medicinal plants of east and Southeast Asia. MIT press, Cambridge.

Philips, D.I., D.J. Barker, C.H. Fall, J.R. Seckl, C.B. Whorwood, P.J. Wood and B.R. Walker (1998). Elevated plasma cortisol concentrations: a link between low birth weight and the insulin resistance syndrome? J. Clin. Endocrinol. Metab, 83: 757-760.

Ross, M.G. and M. Desai (2005). Gestational programming: population survival effects of drought and famine during pregnancy. Am. J. Physiol. Regul. Integr. Comp. Physiol. 288: R25-33.

Seckl, J.R. (1998). Physiologic programming of the fetus. Clin. Perinatol. 25: 939-962.

Seckl JR, Walker BR (2001). $11 \beta$-hydroxysteroid dehydrogenase type $1-$ a tissue-specific amplifier of glucocorticoid action. Endocrinology 142: 1371-1376.

Seckl JR (2004). Prenatal glucocorticoids and longterm programming. Eur $J$ Endocrinol 151: U49-U62.

Smith JT, Waddell BJ (2002). Leptin receptor expression in the ratplacenta: changes in $\mathrm{Ob}-\mathrm{Ra}$, $\mathrm{Ob}-\mathrm{Rb}$ and $\mathrm{Ob}-\mathrm{Re}$ with gestational age and suppression by glucocorticoids. Biology of Reproduction. 67, 1204-1210.

Smith JT, Waddel BJ (2003). Developmental changes in plasma leptin and hypothalamic leptin receptor expression in the rat: peripubertal changes and the emergence of sex differences. J. Endocrinol. 176, 313-319.

Sugden MC, Langdown ML, Munns MJ, Holness MJ (2001). Maternal glucocorticoid treatment modulates placental leptin and leptin receptor expression and materno-fetal leptin physiology during late pregnancy, elicits hypertension associated with hyperleptinemia in the early growth retarded adult offspring. Eur $J$ Endocrinol 145:529-539.

Wang MS, Shi H, Wang KS, Reindenberg MM (2002). Inhibition of 11beta-hydroxysteroid dehydrogenase in guinea pig kidney by three bioflavonoids and their interactions with gossypol. Acta Pharmacol. Sin,;(1):92-96.

Watt JM, Breyer-Brandwijk MG (1962). The medicinal and poisonous plants of southern and eastern Africa. $2^{\text {nd }}$ edition E and S Livingstone Ltd, Edinburgh and London.

Woodall, S.M., B.H. Breier, B.M. Johnston and P.D. Gluckman (1996). A model of intrauterine growth retardation caused by chronic maternal undernutrition in the rat: effects on the somatotrophic axis and postnatal growth. J. Endocrinol. 150: 231-242.

Wu X, Iguchi T, Itoh $\mathrm{N}$, Okamoto K, Takagi T, Tanaka K, Nakanishi T (2008). Ascorbic acid transported by sodium-dependent vitamin $\mathrm{C}$ transporter 2 stimulates steroidogenesis in human choriocarcinoma cells. Endocrinology. 149(1):73-83.

Yajnik C (2006). Nutritional control of foetal growth. Nutr. Rev. 64 (5 Pt 2): S50-1; discussion S72-91. 
Yamashita H, Shao J, Ishizuka T, Klepcyk PJ, Muhlenkamp P, Qiao L, Hoggard N, Friedman JE (2001). Leptin administration prevents spontaneous gestational diabetes in heterozygous Lepr(db/+) mice: effects on placental leptin and fetal growth. Endocrinology 142:2888-2897.

Zhang YR, Proenca M, Maffei M, Barone L, Leopole J, Friedmam (1994). Positional cloning of the mouse obese geneand its human homologue. Nature (Lond) 372: 425-432.

Zhang YD, Wang MS (1997). Inhibition of 11 betahydroxysteroid dehydrogenase obtained from guinea pig kidney by some bioflavonoids and triterpenoids. Zhongguo Yao Li Xие Bao 8 (3): 240-244. 